\title{
The Effect of Internal Control Disclosure on Financial Information Quality and Market Performance distinguished by the Corporate Governance Index
}

\author{
Weli \\ Fakultas Ekonomi dan Bisnis \\ Universitas Katolik Indonesia Atma Jaya Jakarta, Indonesia \\ E-mail: weli.imbiri@gmail.com \\ Julianti Sjarief \\ Fakultas Ekonomi dan Bisnis \\ Universitas Katolik Indonesia Atma Jaya Jakarta, Indonesia \\ E-mail: julianti.sjarief@gmail.com
}

Received: February 26, 2018

Accepted: March 7, 2018

Published: March 14, 2018

doi:10.5296/ijafr.v8i1.12823

URL: https://doi.org/10.5296/ijafr.v8i1.12823

\begin{abstract}
Corporate disclosure practice of internal control in Indonesia remains non-mandatory and limited in nature. This study was conducted to analyze the level of internal control disclosure in the annual reports of Indonesian public corporations and identify its consequences on the firm's market performance and financial information quality, which was differentiated by corporate governance index. This index refers to the Corporate Governance Perception Index released by the Indonesian Institute for Corporate Governance in 2014 and 2015. Based on the conducted content analysis, it can be concluded that the disclosure of internal control by public corporations in Indonesia is still at an intermediate level. The influence of extensive internal control information disclosure on market performance is strengthened by the accounting information quality. And the influence of the relationship between extensive disclosure and firm performance is different between CGPI-indexed companies and those which are unindexed by CGPI. The findings of this research contribute to future researches related to internal control disclosure. Limitations and suggestions can be found at the end of this study.
\end{abstract}


Keywords: Corporate government index, Quality of financial information, Internal control disclosure, Firm performance

\section{JEL Classifications: M41, M48}

\section{Introduction}

Internal control is widely defined by Ghosh \& Lubberink (2006) as a process performed by a company's board of directors, management, and other personnel which is designed to give adequate certainty regarding (1) the company's operation effectiveness and efficiency, (2) reliability of financial statements, and (3) compliance with the applicable law and regulations. From this definition, it is expected therefore that the information about the application of a company's internal control would be quite helpful for stakeholders to find out the effectiveness of the company's business process. Nevertheless, the access to such information on internal control condition is not easy to get since the arrangement related to disclosure of internal control information has not been governed in detail. As a result, the practice of disclosure regarding the internal control of companies in Indonesia is still varied. In this country, the information on internal control is presented only in such sections as statement of management responsibility and the assessment made by the management on the effectiveness of company's internal control over the financial statements, yet some companies have presented the information on internal control adequately (Sjarief \& Weli, 2016).

The presentation of information on internal control by a company is a part of good governance which includes fairness, transparency, accountability and responsibility. This can be done by presenting information adequately to stakeholders. Therefore, the application of good governance is expected to influence the quality of financial information (Agyei-Mensah, 2016; Mensah, Aboagye, Addo, \& Buatsi, 2003). In line with the transparency principle companies are expected to make a disclosure on important information the stakeholders need to know, including the company's internal control condition. The objective of application of internal control by a company is to have a reliable reporting system (other than the operation efficiency and effectiveness as well as assurance of compliance with the applicable law and regulations), thus internal control is believed to have some influence on the quality of the company's information presented in the form of financial statements. Therefore, the company's successful application of good governance can be seen from the internal control system disclosed transparently as well as other financial information which can be used by the stakeholders.

The previous studies in Indonesia about the application of internal control system of a company and the good corporate governance practices find that they have some influence on the prevention of fraud, particularly in the presentation of financial statements (Pratolo S, 2007; Gusnardi, 2011; Suyono \& Hariyanto, 2012; Sari, 2012). The presentation of information to stakeholders constitutes an important part, considering their interest in their investment activity in the company. This is because a decision to make investments is mostly made based on the financial information the company presents. Hence, the presentation of financial statements highly influences investors' decision and trust. Therefore, the company ought to present high-quality financial statements in order to reduce information asymmetry between 
the company's stakeholders as illustrated in agency theory (Watts \& Zimmerman, 1986). Otherwise, information asymmetry would cause conflict of interest which result in excessive exploitation of company's resources and in the end it will harm many parties.

To prevent managers from exercising opportunistic behavior, agency theory recommends companies to establish an effective monitoring mechanism. As one of monitoring mechanisms, corporate internal control system is formed to minimize any possible fraud potential in the company. Results of previously conducted empirical studies indicate that the quality of financial statements increases when the corporate internal control system improves (Lambert, Leuz, \& Verrecchia, 2007; Ashbaugh-Skaife H. , Collins, Kinney Jr, \& LaFond, 2008). Furthermore, high-quality reports will increase investment efficiency (Lambert, Leuz, \& Verrecchia, 2007; Biddle, Hilary, \& Verdi, 2009). In turn, the efficiency of the investments made by investors will lift the company's value as reflected from the company's share price.

Additionally, the application of good corporate governance will also drive the company's management to make an extensive information disclosure with no exception on the internal control system. This efforts is consistent with the signaling theory where the management will disclose their internal control condition to the public as a signal of effectiveness in running their business operation.

Based on this background, this research will analyze the influence of a company's financial statements quality and corporate governance quality on the relationship between internal control information disclosure level and market performance. The corporate governance quality in this research will use the index issued by The Indonesian Institute for Corporate Governance (IICG 2015), assuming that any company indexed therein is the one with good corporate governance quality. From there, the questions of this research can be formulated as follows:

1. How is the disclosure level of information on internal control in the annual reports of those companies indexed and non-indexed by IICG?

2. How is the relationship between the quality of financial information and the market performance of public companies with extensive disclosure of information on internal control in their annual reports?

3. Is the relationship between the quality of financial information and the market performance of public companies with extensive disclosure of information on internal control in their annual reports different between those indexed and non-indexed by IICG?

\section{Literature Review and Hypothesis}

The theories underlying this research are Agency Theory and Signaling Theory. The concept of Agency Theory is used to explain the disclosure of relevant information on the company transparently by the management and it is intended to reduce any conflict of interest and decrease any uncertainty in the presentation of information. Thereby, it could create a harmony of interets which can reduce earnings management. Meanwhile, Signaling Theory is used to explain the management behavior in presenting their financial information as a signal to the 
investors to convince them about the company's good condition, including their financial performance and corporate governance. Thus, good governance can be used as a signal which indicates the absence of manipulation to the revenues by the company as presented in their financial information and therefore this signal is expected to decrease any information asymmetry in the market.

\subsection{Disclosure of Internal Control Information}

Information on a company's internal control condition can only be discovered in such sections as Statement of Management Responsibility and the Assessment Made by the Management on the Effectiveness of the Company's Internal Control over the Financial Statements, attestation report in the management assessment of the company's internal control over the financial statements by public accountant. Such information has not been sufficient even though disclosure has been governed by the government in the Regulation Number X.K.6 of attachment to Decision of Bapepam Chief and LK Number: Kep-431/BL/2012 concerning the submission of Annual Reports of Issuers or Public Companies. Such arrangement only implies the explanation of internal control applied by companies at least about financial and operational controls as well as compliance with other regulations of law, the review made by the companies in relation to the effectiveness of their internal control system. The response to this decision of BAPEPAM has resulted in varied disclosure among companies (Sjarief \& Weli, 2016). This is consistent with Schneider \& Church's (2008) opinion which states that the disclosure of internal control condition in financial statements has resulted in quite long debates or pros and cons among elements. The variations in research findings about disclosure are interesting topics to be studied, especially in Indonesia because disclosure methods and formats are still voluntary. Of course, this voluntary disclosure will be affected by some conditions that ultimately benefit the users.

Results of previous empirical studies on disclosure of internal control condition in financial statements indicate that it influences the decisions made by investors (Rose, Norman, \& Rose, 2010; Lopez, Vandervelde, \& Wu, 2009; Waller \& Whittington, 2008; Holt \& DeZoort, 2009) and creditors (Schneider \& Church, 2008; Kim, Song, \& Zhang, 2011). Nevertheless, other studies find that disclosure of a company's internal control weakness has no influence on the intention to invest, yet it influences the investment decision (Schneider A., 2009). Therefore, this issue becomes interesting to study to see how information on internal control given by companies in Indonesia has been responded to by their stakeholders.

\subsection{Financial Information Quality}

Financial information quality is a topic many studies have discussed due to some scandals of financial statements. Financial information quality has been defined differently by several experts for there has been no right definition for financial information quality. Nevertheless, IASB has determined on the components of accounting quality which consists of relevance, faithful representation, comparability, verifiability, timeliness, and understandability.

This accounting quality reflects the quality of the financial information presented by the company. However, the measurement frequently used in assessing accounting quality in 
previous studies is earning management. Earning management is a judgement made by managers in the process of preparing financial statements, such as the selection of depreciation method, receivable reserve method, and inventory assessment. In turn, the financial statements will present misleading performance information for stakeholders.

That is why this research will assess the financial information quality using earning management measurement as seen from the discretionary accruals. Accounting accruals are the difference between earnings and cash flow from the operation activities, consisting of discretionary and non-discretionary accruals. Discretionary accruals occurs when the managers transfer the profit of another period using an accounting method. As a consequence, the use of disretionary accruals will influence the quality of financial statements information. The lower the discretionary accrual, the better the statements quality would be, and vice versa. The problem is that high-quality financial statements should actually illustrate the company's overal performance as reflected in the company's quality profit for the current time and it can be an good indicator in the future (Lev \& Thiagarajan, 1993; Penman \& Zhang, 1999; Richardson, Sloan, Soliman, \& Tuna, 2001; Beneish \& Vargus, 2002; Rhichardson, 2003), in addition it also reflects a good operation cash flow (Dechow and Dichev 2002; Cohen, 2003).

\subsection{Extensive Disclosure of Internal Control Information and Financial Information Quality}

A good internal control will result in reliable financial statements, when all of the company's personnel including those individual involved in the accounting procedures have followed the internal control principles as their work guidelines. This gives certainty of the achievement of effectiveness of corporate internal control system which can improve the reliability of financial statements and in turn would reduce the risk of material misrepresentation or fraud. The same applies to the business operation survival because all business activities the company performs have been complied with the guidelines in the predetermined principles. Therefore, a good internal control system is a reflection of a good corporate governance. To the contrary, when there is a failure in implementing this internal control, it will then give a significant contribution to a poor corporate governance (Njanike, Mutengezanwa, \& Gombarume, 2011; Dănescu, Prozan, \& Dănescu, 2011). Hence, internal control system can give an assurance of reliable financial statements, efficient and effective operation and compliance with the law and regulations (Suyono \& Hariyanto, 2012) and likewise the quality of information revealed by the company (Michelon, Bozzolan, \& Beretta, 2015).

The quality of corporate governance implementation is highly determinant to the transparency of information provided by the company because the principles of corporate governance include such matters as fairness, transparency, accountability and responsibility which are related to information disclosure. These principles should be able to ensure that the shareholders get their rights of obtaining accurate and timely information. This way the company would seem to have indicated their good faith in making the disclosure accurately, timely and transparently to all information on the firm performance, ownership and stakeholders. Hence, Corporate Governance is a guideline for managers to manage the company using the best practices and to make financial decisions from which the stakeholder could benefit. 


\section{$\Lambda$ Macrothink}

International Journal of Accounting and Financial Reporting ISSN 2162-3082

To lower the management tendency to make an earning management, the monitoring mechanism of the corporate governance system plays an important role. Previous studies show that the good governance practice will have something to do with effective internal control system, thus the management would behave in a way which follows the applicable mechanism (Agyei-Mensah, 2016; Fathi, 2013; Chang \& Sun, 2008; Jiang, Lee, \& Anandarajan, 2008; Mensah, Aboagye, Addo, \& Buatsi, 2003). Therefore, it is of utmost importance for the stakeholders to receive the certainty of good practice from the management through the information disclosed in regard to the application of governance and the internal control system implemented by the company.

Considering the detrimental effect of failing to implement an internal control on the corporate governance (Njanike, Mutengezanwa, \& Gombarume, 2011), there is a need to widely and adequately implement internal control to reach a good corporate governance (Dănescu, Prozan, \& Dănescu, 2011). This internal control can provide an assurance of reliable financial statements, efficient and effective operations pursuant with the law and regulations (Suyono $\&$ Hariyanto, 2012). Therefore, when the internal control in an organization is managed well, the right and appropriate good governance practice can automatically be improved.

The previous empirical studies testing the relationship between internal control disclosure and corporate governance generally relate them to a governance mechanism, such as monitoring by board of commissioners (Owusu-Ansah \& Ganguli, 2010; Deumes R. W., 2000; Michelon, Bozzolan, \& Beretta, 2015; Deumes \& Knechel, 2008; Jianfei \& Yiran, 2011). Results of these studies also indicate different findings thanks to the use of different governance characteristic variables. However, they give a clue that there is a strong relationship between monitoring and the information disclosed by the company (Altamuro \& Beatty, 2010; Michelon, Bozzolan, \& Beretta, 2015). That is why this research will analyze the relationship between a company's extensive internal control disclosure and its financial information quality. It is expected that extensive disclosure of the company's internal control conditions relates to the quality of the financial information submitted by the company. This can happen given the concept of transparency of good corporate governance as well as the signaling theory underlying this research.

\subsection{Financial Information Quality and Market Performance}

One of the means one can use to realize information transparency is financial statements. The information presented therein will be used by stakeholders to make many important decisions. The financial information required by their users is the high-quality one which will enable them to make insightful decision and to explain or predict the share price and return (Bernard $\&$ Stober, 1989). When the presented information fails to show the real fact about the management performance, it can mislead their users.

Earning management in the reported profit information causes the failure of these financial statements to focus on the general needs of their users, they rather move towards the interest of certain parties. Hence, high-quality accounting profit information should reflect the company's real financial performance. Nevertheless, results of previous studies show that some managements try to make earning management due to the application of accrual concept in 
accounting, making the financial information quality biased, and failing to reflect the company's real performance accurately. Meanwhile, accurate information is expected to be helpful for the company both for now and in the future and it can even reflect the earning continuance (Dechow \& Schrand, 2004; Penman, 2007; Tong \& Miao, 2011).

Companies with good governance is expected to receive positive response from their stakeholders. It can be understood when it is related to the function and objective of applying good corporate governance, i.e. to provide certainty that the business process practiced is in compliance with the applicable regulations and provisions. Thereby, it will reduce the risk of making incorrect decisions and this will influence the company's value. Previous studies reveal that there is some relationship between financial information quality and market performance. The market performance which is valued with the future share price is influenced by low financial information quality (Siagian, Siregar, \& Rahadian, 2013; Chan, Chan, Jegadeesh, \& Lakonishok, 2001; Suranta \& Midiastuty, 2005).

\subsection{Corporate Goverance Perception Index (CGPI)}

In this research the Corporate Governance quality is seen from the Corporate Governance Perception Index (CGPI). CGPI is an annual program from Indonesian Institute Corporate Governance (IICG) who perform some assessments and rank the application of GCG in companies in Indonesia since 2001(www.iicg.org). Such ranking is of volunteer nature where the company's participation is elective and voluntary without being underlain by the drive to comply with some rules (mandatory) and considering the company's internal preparedness (selective) in deciding to participate in CGPI based on the assessment themes. The assessment criteria consist of self-assessment, document assessment, paper assessment and observation.

The assumption underlying this research to use CGPI is that the companies participating in this ranking program are those with good corporate governance, hence they voluntarily take part in this ranking program. Thus, it is assumed that the companies indexed by CGPI are those with better corporate governance. High-quality Corporate Governance indicates that the companies manage their resources more transparently and it is a promotion to the business process efficiency. In addition, the internal control principles which constitute the functions of corporate governance are believed to influence the financial statements quality, leading to information contained in financial statements being capable of showing the performance achieved by the company. This way their stakeholders can use this information for decision-making. This investor's trust level has positive relationship with market performance.

Based on the description above, the research hypotheses can be formulated as follows:

H1: Extensive internal control information disclosure has some influence on the firm performance which is moderated by financial information quality.

H2: CGPI Index has some influence on the relationship between extensive disclosure and firm performance. 


\section{Research Method}

The population of this research is 12 companies indexed by CGPI and they are compared to 37 control companies unindexed by CGPI for the assessment of fiscal years 2014 and 2015 by IICG (The Indonesian Institute for Corporate Governance), hence they make up for 98 research samples. The control companies are selected randomly, yet they are chosen according to the industry or characteristics of those indexed. The data are collected and processed using quantitative content analysis. Quantitative content analysis is used to dissect the text content in those companies' annual reports regarding their internal control systems according to the index list in the list of disclosure item of internal control system they have made. The data are analyzed using descriptive statistics to illustrate and describe the general picture and every research variable by seeing the score of each disclosure item. The hypotheses are tested using Multiple Regression Test and the Moderation is tested using Sub-Group Test which is done using IBM SPSS 22 program.

\section{Operationalization of Variables and Their Measurement}

\subsection{Internal Control System Disclosure}

In accordance with the provisions of Bapepem X.K.6 2102, the items of internal control disclosure required to be included at least about a) financial and operational controls, and the compliance with other regulations of law; and b) review of the effectiveness of internal control system. From this fact, the internal control disclosure level in this research is measured using unweighted index or using Dichotomous Score. Finally, the items of internal control disclosure are assessed using the instruments adopted from Van de Poel \& Vanstraelen (2011) research.

\subsection{Quality of Financial Information}

Financial information quality is measured by discretionary accrual which is counted using the difference between total accrual and non discretionary accrual, estimated using The Modified Jones Model as explained by Dechow, Sloan, \& Sweeney (1995). In this measurement, earnings are said to be of quality when they have small total accrual change, which assumed as a change of discretionary accrual. The closer the discretionary accrual value to zero, the higher the reported earning quality. A discretionary accrual close to zero shows the low earning management.

\subsection{Market Performance}

Market performance is used to measure the company's achievement from external perspective or assessment by the market. Thus, this research will use Tobin's Q assessment, where the market assessment is done to the company's assets and debts. The principle of Tobin's Q is when the share which will deliver profit in the future is sold at a price higher than the investment cost, then the company receives incentives to produce a new investment model. The greater the Tobin's Q value the better the company's growth prospect and the greater their intangible assets. 


\section{Mll Macrothink}

International Journal of Accounting and Financial Reporting

ISSN 2162-3082

2018, Vol. 8, No. 1

\section{Results and Discussion}

\subsection{Extensive Internal Control Disclosure}

Extensive internal control information disclosure is distinguished into 2 (two) parts, namely: 1) financial and operational internal control information and the compliance with other regulations of law, 2) information related to the review of effectiveness of internal control system. There are only 2 (two) items in the first part disclosed by all companies, i.e. about the activity of managing risks (A5) and compliance with audit committee (A6). The same applies to B where only 2 items are disclosed by all companies, they are the Role of board of commissioners (B2) and the Role of audit committee in corporate internal control system (B3). The results of score calculation show that the item on Significant change in the internal control system is not found in all companies (A10), while the item on specific risks (A9) is disclosed only by $12 \%$ of these companies. The information on review activities which are very rarely disclosed is the one on the company's policies which refer to adoption of international standards, guidelines or criteria of internal control such as COSO (B10), the Role of external auditor in corporate internal control system (B4) and There is a discussion on internal control in the meetings of board of directors/commissioners (B6). Other items have not been disclosed in detil by almost all companies. Detailed descriptions on the items disclosed by these companies can be seen in Tables $1 \mathrm{a}$ and $1 \mathrm{~b}$.

Table 1a. Disclosure items of financial and operational internal control information and the compliance with other regulations of law

\begin{tabular}{|c|c|c|c|}
\hline Code & Internal Control Items & $\mathbf{N}$ & Percent \\
\hline A5 & Risk Management Activities & 49 & $100 \%$ \\
\hline A6 & Audit Committee & 49 & $100 \%$ \\
\hline A4 & Internal audit function in corporate internal control system & 48 & $98 \%$ \\
\hline A8 & Whistleblower system & 42 & $86 \%$ \\
\hline A7 & Company's Code of Conduct & 40 & $82 \%$ \\
\hline $\mathrm{A} 2$ & Internal control coverage & 35 & $71 \%$ \\
\hline A1 & Internal control description & 34 & $69 \%$ \\
\hline A3 & Internal control objectives & 33 & $67 \%$ \\
\hline A9 & Specific risks & 6 & $12 \%$ \\
\hline \multirow[t]{2}{*}{ A10 } & Significant change in corporate internal control system & 0 & $0 \%$ \\
\hline & Average & 17 & $69 \%$ \\
\hline
\end{tabular}




\section{Mll Macrothink}

International Journal of Accounting and Financial Reporting

ISSN 2162-3082

2018, Vol. 8, No. 1

Table 1b. Disclosure items of information related to the review of effectiveness of internal control system

\begin{tabular}{llrr}
\hline Code & \multicolumn{1}{c}{ Internal Control Items } & N & Percent \\
\hline B2 & the Role of board of commissioners in corporate internal control system & 49 & $100 \%$ \\
\hline B3 & the Role of audit committee in corporate internal control system & 49 & $100 \%$ \\
\hline B5 & the Statement of manager assessing the quality of financial statements & 48 & $98 \%$ \\
\hline B8 & The management's responsibility in relation to the application of internal control & 48 & $98 \%$ \\
\hline B9 & There is a statement of internal control in the financial statements & 48 & $98 \%$ \\
\hline B7 & The assessment of the internal control system effectiveness & 47 & $96 \%$ \\
\hline B1 & Management Statetment of the internal control system effectiveness & 46 & $94 \%$ \\
\hline & The company's policies which refer to adoption of international standards, guidelines or & 26 & $53 \%$ \\
B10 & criteria of internal control such as COSO & 12 & $24 \%$ \\
\hline B4 & The Role of external auditor in corporate internal control system & of & 7 \\
\hline & $\begin{array}{l}\text { There is a discussion on internal control in the meetings of } \\
\text { B6 }\end{array}$ directors/commissioners & $14 \%$ \\
\hline & & Average & 19 \\
\hline
\end{tabular}

Furthermore, when viewed from the disclosure practice by these companies regarding their internal control conditions as summed up in Table 2, it can be seen that only 66 companies (67.3\%) have the index scores equal to and more than 0.75 . This number tells that not all companies have disclosed all items of internal control under assessment or, in other words, the disclosure level in public companies in Indonesia is relatively medium. The description of relationship between extensive internal control disclosure and accounting quality variables, and between firm performance and CG index variables can be seen in the summary presented in Table 2.

Table 2. Crosstabulation

\begin{tabular}{|c|c|c|c|c|c|c|c|c|c|c|c|}
\hline & & \multicolumn{3}{|c|}{ Accounting Quality } & \multicolumn{4}{|c|}{ Firm Performance } & \multicolumn{3}{|c|}{ CGPI Index } \\
\hline & & $<=0$ & $>0$ & Total & $<1$ & $1-1.5$ & $>1.5$ & Total & No & Yes & Total \\
\hline \multirow{4}{*}{$\begin{array}{c}\text { Disclosure } \\
\text { Indeks }\end{array}$} & $0.35-0.54$ & 8 & 0 & 8 & 2 & 0 & 6 & 8 & 8 & 0 & 8 \\
\hline & $0.55-0.74$ & 17 & 7 & 24 & 6 & 16 & 2 & 24 & 43 & 3 & 46 \\
\hline & $0.75-0.95$ & 44 & 22 & 66 & 10 & 46 & 9 & 65 & 24 & 20 & 44 \\
\hline & Total & 69 & 29 & 98 & 18 & 62 & 17 & 97 & 75 & 23 & 98 \\
\hline
\end{tabular}

\subsection{Assumption Test}

Before conducting the statistic testing for hypotheses, assumption test has been performed on the research data. After excluding several outlier data, the final number of processable data becomes 85 from initially 98. 


\section{Autocorrelation Test}

The autocorrelation testing is done by seeing the Durbin-Watson (DW) value, and the results of SPSS output gives a DW value of 1.758. This value is greater than du (1.5752) and less than $4 \mathrm{du}$ (2.4248). Therefore, it can be concluded that there is no autocorrelation ( $\mathrm{dl}$ and $\mathrm{du}$ values for independent variables amounting to 3 and the sample amounting to 85 are $\mathrm{dl}=1.5752$ and $\mathrm{du}=1.7210)$.

\section{Heteroscedasticity test}

The heteroscedasticity test is done by vieweing the scatterplots graph, whether the points spread randomly above and below 0 in $\mathrm{Y}$ axis. The results of scatterplots graph (see appendix) generated by SPSSS indicate that the points spread randomly above and below 0 in $\mathrm{Y}$ axis, thus it can be concluded that there is no heteroscedasticity occuring. In addition to a graph, the results Spearman's Rho correlation coefficient test also shows that there is no heteroscedasticity issue in the regression model because the extensive variable correlation value with Unstandardized Residual has a significance value ( $\mathrm{p}$-value) greater than 0.05 .

\section{Normality Test}

Based on the normal plot graph of SPSS output, it can be concluded that the model meets the normality assumption because the data spread around the line and follow the diagonal line direction which shows a normal distribution pattern. Meanwhile, the results of Kolmogorov-Smirnov normality test show that the Asymp. Sig. (2-tailed) value is 0.173. Since this Asymp. Sig. value is greater than 0.05 , it can then be concluded that the data are distributed normally.

Judging from the results of assumption test above, it can then be concluded that the data can be used for testing the hypotheses with regression model.

\subsection{Hypothesis Test}

Using sub-group moderation analysis, the SPSS output of model summary for DQ0 $=1$ (low Discretionary accruals) indicates an Adjusted $\mathrm{R}^{2}$ value of 0.141 , while for $\mathrm{DQ} 0=0$ (high Discretionary accrual) the Adjusted $R^{2}$ value is 0.116 . Because the Adjusted $R^{2} D Q 0=1$ value is greather than that of Adjusted $\mathrm{R}^{2} \mathrm{DQ} 0=0$, it can then be concluded that financial information quality (DQ0) variable is the moderating variable. In other words, the influence of extensive internal control information disclosure (extensive) on market performance (T0) in companies with low discretionary accrual $(\mathrm{DQ} 0=1)$ is stronger than in companies with high discretionary accrual (DQ0 $=0)$.

The SPSS output of model summary for CG=1 (CGPI-indexed) shows that the Adjusted $\mathrm{R}^{2}$ value is -0.033 , while for $\mathrm{CG}=0$ (unindexed by $\mathrm{CGPI}$ ) the value is 0.145 . Because the Adjusted $\mathrm{R}^{2} \mathrm{CG}=0$ value is greater than that of Adjusted $\mathrm{R}^{2} \mathrm{CG}=1$, it can then be concluded that $\mathrm{CG}$ variable is a moderating variable. In other words, the influence of extensive internal control disclosure on T0 (market performance) in companies unindexed by CGPI $(C G=0)$ is stronger than in companies indexed by CGPI $(\mathrm{CG}=1)$. However, the result of independent samples test on whether extensive internal control disclosure is different among the 
IICG-indexed companies dan the unindexed one shows mean value difference for the variable of extent between both types of company ( $p<0.05$ ). The indexed company's mean is higher than that of their unindexed counterparts, hence it can be concluded that the disclosure level of IICG-indexed company is more extensive than the disclosure level of those unindexed by IICG.

\subsection{Discussion}

The descriptive analysis result shows that the internal control information item related to Financial and Operational Control, and Compliance With Other Regulations of Law disclosed by all companies is the Activity of Managing Risks, and Compliance about the Existence of Audit Committee. Another item related to the Function of internal audit in the company's internal control has been disclosed by almost all companies and only 1 company does not disclose it. Meanwhile, another information particularly regarding the Scope of Internal Control, Description of Internal Control System, and Objective of Corporate Internal Control System are disclosed only by less than $70 \%$ of the company sample. The information many companies do not disclose is about Specific Risks, where it is only disclosed by $12 \%$ of the sample companies.

The next information about internal control information disclosure is related with the activity of Review of Effectiveness of internal control system. The item disclosed by all companies only deal with the Role of board of commissioners and the Role of audit committee in corporate internal control system. The item related to the Statement of manager assessing the quality of financial statements, management's responsibility in relation to the application of internal control and Statement of internal control in the financial statements have been revealed by almost all companies and only 1 company does not disclose it. Likewise, the information about the existence of activity of assessing the effectiveness of internal control system and Statement from the management about the effectiveness of internal control have been disclosed by almost all sample companies and only 2 companies have not disclosed it. The information on the Company's policy in reference to the adoptions of international standards, guidelines or criteria of internal control such as COSO is disclosed only by 26 sample companies. Meanwhile, the information on the role of external auditor in corporate internal control system is revealed only 12 of sample companies while the item of the Function of internal audit in the company's internal control has not been disclosed by 48 companies. This shows that external auditor has not played a role yet in the corporate internal control system. The same applies to the item on the Existence of discussion on internal control in meetings of board of directors/commissioners which is disclosed only by $14 \%$ of the sample companies.

This result indicates that these companies only suffice themselves by giving minimum response to what the Financial Services Authority (OJK) requires, i.e. in relation to internal control system and risk managemen in general. According to Regulation Number X.K.6 of attachment to Decision of Bapepam Chief and LK Number: Kep-431/BL/2012 on Submission of Annual Reports of Issuers or Public Companies, which governs, among other things, that the issuing companies must disclose their Internal Control System and risk 
management, Code of Conduct and Corporate culture along with its implementation and Whistleblowing system. However, the analysis results show that Whistleblower and Code of Conduct are disclosed only by $85 \%$ and $82 \%$ of all samples. It can be understood since there has been no technical guidelines about the detailed information about internal control system they are required to disclose in their annual reports.

The result of analysis of the moderating influence supports hypothesis 1 , meaning that the influence of extensive internal control information disclosure on market performance is strengthened by the accounting information quality. High-quality financial statements as characterized by the low discretionary accrual value will increase the influence of extensive disclosure on market performance. This confirms the Agency theory which suggests that in order to reduce uncertainty in the presentation of information, the management ought to try to disclose the relevant information transparently. According to signalling theory, this research result indicates that those companies have given positive signal on the accounting information quality they have presented, thus the stakeholders respond to it in a positive way as shown by its influence on market performance.

The result of analysis of the influence of CGPI index supports hypothesis 2, meaning that the influence of the relationship between extensive disclosure and firm performance is different between CGPI-indexed companies and those which are unindexed by CGPI. Nevertheless, this result does not prove that the indexed companies have better corporate governance than their unindexed counterparts. It means that the perception that indexed companies are those companies with better corporate governance is not proven. Thus, those unindexed companies do not necessarily have poorer corporate governance.

\section{Conclusion}

This research gives an empirical support to the relationship between extensive disclosure, particularly regarding internal control information, and market performance. The issuers respond positively to the requirement to disclose internal control information in their financial statements despite being less detailed. The influence of extensive disclosure on market performance is moderated by accounting information quality. The companies disclosing their internal control in detail/extensively show better market performance, particularly those companies with low discretionary accrual.

In addition to its contribution to research related to internal control, this research has its limitation in its non-random sampling. This is because the research compare the condition between CGPI-indexed companies and their unindexed counterparts. The analysis results cannot be generalized and it is possible for them to be biased because CGPI index is voluntary, leading to the possibility that unindexed companies have equal or even better governance quality than the indexed ones.Therefore, there is a need to perform further research using other components of Corporate Governance assessment to obtain some results which reflect better the relationship between extensive disclosure and market performance. 


\section{References}

Agyei-Mensah, B. K. (2016). Internal Control Information Disclosure and Corporate Governance: Evidence From an Emerging Market. Corporate Governance: The International Journal of Business in Society, 16(1). https://doi.org/10.1108/CG-10-2015-0136

Altamuro, J., \& Beatty, A. (2010). How Does Internal Control Regulation Affect Financial

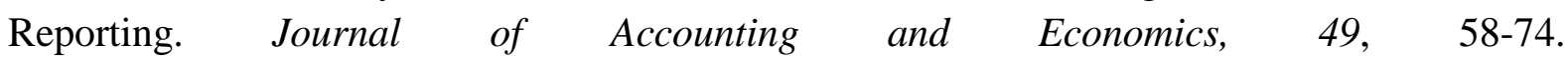
https://doi.org/10.1016/j.jacceco.2009.07.002

Ashbaugh-Skaife, H., Collins, D. W., \& Kinney, W. R. (2007). The discovery and reporting of internal control deficiencies prior to SOX-mandated audits. Journal of Accounting and Economics, 44(1), 166-192. https://doi.org/10.1016/j.jacceco.2006.10.001

Ashbaugh-Skaife, H., Collins, D. W., Kinney Jr, W. R., \& LaFond, R. (2008). The effect of SOX internal control deficiencies and their remediation on accrual quality. The Accounting Review, 83(1), 217-250. https://doi.org/10.2308/accr.2008.83.1.217

Beneish, M., \& Vargus, M. (2002). Insider Trading, Earnings Quality, and Accrual Mispricing. The Accounting Review, 77(4), 755-791. https://doi.org/10.2308/accr.2002.77.4.755

Bernard, V. L., \& Stober, T. L. (1989). The nature and amount of information in cash flows and accruals. Accounting Review, 624-652.

Biddle, G. C., Hilary, G., \& Verdi, R. S. (2009). How does financial reporting quality relate to investment efficiency? Journal of Accounting and Economics, 48(2), 112-131. https://doi.org/10.1016/j.jacceco.2009.09.001

Chan, K., Chan, L. K., Jegadeesh, N., \& Lakonishok, J. (2001). Earnings quality and stock returns (No. w8308). National bureau of economic research. https://doi.org/10.3386/w8308

Chang, J. C., \& Sun, H. L. (2008). The relation between earning in formativeness, earnings management and corporate governance in the pre-and post-SOX periods. AAA Mid-Atlantic Region Meeting, (pp. 24-26).

Cohen, D. (2003). Quality of Financial Reporting Choice: Determinants and Economic Consequences. Working Paper, Northwestern University Collins. https://doi.org/10.2139/ssrn.422581

Dănescu, T., Prozan, M., \& Dănescu, A. (2011). Risk management model in insuring good corporative governance. Severin Conference - WSEAS and IAASAT Conferences.

Dechow, P. M., \& Dichev, I. D. (2002). The quality of accruals and earnings; The role of accrual estimation errors. The Accounting Review, 77(s-1), 35-59. https://doi.org/10.2308/accr.2002.77.s-1.35

Dechow, P. M., Sloan, R. G., \& Sweeney, A. P. (1995). Detecting earnings management. Accounting review, 193-225. 


\section{Mll Macrothink}

International Journal of Accounting and Financial Reporting ISSN 2162-3082 2018, Vol. 8, No. 1

Dechow, P., \& Schrand, C. (2004). Earnings quality. The Research Foundation of CFA Institute.

Deumes, R. W. (2000). Voluntary reporting on internal control by listed Dutch companies. Maastricht: Maastricht Accounting and Auditing Research and Education Center (MARC).

Deumes, R., \& Knechel, W. R. (2008). Economic incentives for voluntary reporting on internal risk management and control systems. Auditing: A Journal of Practice \& Theory, 27(1), 35-66. https://doi.org/10.2308/aud.2008.27.1.35

Fathi, J. (2013). Corporate governance system and quality of financial information. $\begin{array}{lllll}\text { Mediterranean Journal of } & \text { Social } & \text { Sciences, } & 4(2), & \end{array}$ https://doi.org/10.5901/mjss.2013.v4n2p129

Ghosh, A., \& Lubberink, M. (2006). Timeliness and mandated disclosures on internal controls under section 404. American Accounting Association Meetings.

Gusnardi, G. (2011). Pengaruh Peran Komite Audit, Pengendalian Internal, Audit Internal dan Pelaksanaan Tata Kelola Perusahaan Terhadap Pencegahan Kecurangan. EKUITAS (Jurnal Ekonomi dan Keuangan), 15(1), 130-146. https://doi.org/10.24034/j25485024.y2011.v15.i1.2283

Holt, T. P., \& DeZoort, T. (2009). The effects of internal audit report disclosure on investor confidence and investment decisions. International Journal of Auditing, 13(1), 61-77. https://doi.org/10.1111/j.1099-1123.2008.00391.x

Huang, S. M., Ou, C. S., Chen, C. M., \& Lin, B. (2006). An empirical study of relationship between IT investment and firm performance: A resource-based perspective. European Journal of Operational Research, 173(3), 984-999. https://doi.org/10.1016/j.ejor.2005.06.013

Jianfei, L., \& Yiran, D. (2011). Internal control disclosure and corporate governance: empirical research from Chinese listed companies. Technology and Investment.

Jiang, W., Lee, P., \& Anandarajan, A. (2008). The association between corporate governance and earnings quality: Further evidence using the GOV-Score. Advances in Accounting, 24(2), 191-201. https://doi.org/10.1016/j.adiac.2008.08.011

Kim, J. B., Song, B. Y., \& Zhang, L. (2011). Internal control weakness and bank loan contracting: Evidence from SOX Section 404 disclosures. The Accounting Review, 86(4), 1157-1188. https://doi.org/10.2308/accr-10036

Kim, Y., \& Park, M. S. (2009). Market uncertainty and disclosure of internal control deficiencies under the Sarbanes-Oxley Act. Journal of Accounting and Public Policy, 28(5), 419-445. https://doi.org/10.1016/j.jaccpubpol.2009.07.004

Lambert, R., Leuz, C., \& Verrecchia, R. E. (2007). Accounting information, disclosure, and the cost of capital. Journal of Accounting Research, 45(2), 385-420. https://doi.org/10.1111/j.1475-679X.2007.00238.x 


\section{Mll Macrothink}

International Journal of Accounting and Financial Reporting

ISSN 2162-3082

2018, Vol. 8, No. 1

Lev, B., \& Thiagarajan, R. (1993). Fundamental Information Analysis. Journal of Accounting Research, 190-215. https://doi.org/10.2307/2491270

Lopez, T. J., Vandervelde, S. D., \& Wu, Y. J. (2009). Investor perceptions of an auditor's adverse internal control opinion. Journal of Accounting and Public Policy, 28(3), 231-250. https://doi.org/10.1016/j.jaccpubpol.2009.04.003

Mensah, S., Aboagye, K., Addo, E., \& Buatsi, S. (2003, October). Corporate governance and corruption in Ghana: Empirical findings and policy implications. African Capital Markets Forum, Johannesburg, 27-29.

Michelon, G., Bozzolan, S., \& Beretta, S. (2015). Board monitoring and internal control system disclosure in different regulatory environments. Journal of Applied Accounting Research, 16(1), 138-164. https://doi.org/10.1108/JAAR-03-2012-0018

Njanike, K., Mutengezanwa, M., \& Gombarume, F. B. (2011). Internal controls in ensuring good corporate governance in financial Institutions.

Owusu-Ansah, S., \& Ganguli, G. (2010). Voluntary reporting on internal control systems and governance characteristics: An analysis of large US companies. Journal of Managerial Issues, 383-408.

Penman, S. (2007). Financial reporting quality: Is fair value a plus or a minus?. Accounting and Business Research, 37(sup1), 33-44. https://doi.org/10.1080/00014788.2007.9730083

Penman, S., \& Zhang, X. (1999). Accounting Conservatism, the Quality of Earning and Stock Returns. Working Paper, Sosial Science Research Network, 1-44.

Pratolo, S. (2007). Good corporate governance dan kinerja bumn di Indonesia: aspek audit manajemen dan pengendalian intern sebagai variabel eksogen serta tinjauannya pada jenis perusahaan. Simposium Nasional Akuntansi X.

Rhichardson, S. (2003). Earnings Quality and Short Sellers. Supplement. Accounting Horizons, 49-61. https://doi.org/10.2308/acch.2003.17.s-1.49

Richardson, S., Sloan, R., Soliman, M., \& Tuna, I. (2001). Information In Accruals About The Quality o f Earnings. Working Paper, University o f Michigan Business School, 52. https://doi.org/10.2139/ssrn.278308

Rose, J. M., Norman, C. S., \& Rose, A. M. (2010). Perceptions of investment risk associated with material control weakness pervasiveness and disclosure detail. The Accounting Review, 85(5), 1787-1807. https://doi.org/10.2308/accr.2010.85.5.1787

Sari, D. (2012). Pengaruh pengendalian internal terhadap transparansi laporan keuangan Pemerintah Daerah. Seminar Nasional Akuntansi dan Bisnis, pp. 718-727.

Schneider, A. (2009). Auditors' internal control opinions: do they influence judgments about investments?. Managerial Auditing Journal, 24(8), 709-723. https://doi.org/10.1108/02686900910986376 


\section{Mll Macrothink}

International Journal of Accounting and Financial Reporting

ISSN 2162-3082

Schneider, A., \& Church, B. K. (2008). The effect of auditors' internal control opinions on loan decisions. Journal of Accounting and Public Policy, 27(1), 1-18. https://doi.org/10.1016/j.jaccpubpol.2007.11.004

Siagian, F., Siregar, S. V., \& Rahadian, Y. (2013). Corporate governance, reporting quality, and firm value: evidence from Indonesia. Journal of accounting in emerging economies, 3(1), 4-20. https://doi.org/10.1108/20440831311287673

Sjarief, J., \& Weli. (2016). The Internal Control Disclosure, The Executive Compensation, and The Timeliness of Financial Reporting. IJABER, 14(2), 991-1002.

Suranta, E., \& Midiastuty, P. P. (2005). Pengaruh Good Corporate Governance Terhadap Praktek Manajemen Laba. Proceeding Konferensi Nasional Akuntansi: Peran Akuntan dalam Membangun Good Corporate Governance. Konferensi Nasional Akuntansi: Peran Akuntan dalam Membangun Good Corporate Governance.

Suyono, E., \& Hariyanto, E. (2012). Relationship between internal control, internal audit, and organization commitment with good governance: Indonesian case. China-USA Business Review, 11(9).

Tong, Y. H., \& Miao, B. (2011). Are dividends associated with the quality of earnings? Accounting Horizons, 25, 183-205. https://doi.org/10.2308/acch.2011.25.1.183

Van de Poel, K., \& Vanstraelen, A. (2011). Management reporting on internal control and accruals quality: insights from a "comply-or-explain" internal control regime. Auditing: A Journal of Practice \& Theory, 30(3), 181-209. https://doi.org/10.2308/ajpt-10052

Waller Shelton, S., \& Whittington, O. R. (2008). The influence of the auditor's report on investors' evaluations after the Sarbanes-Oxley Act. Managerial Auditing Journal, 23(2), 142-160. https://doi.org/10.1108/02686900810839848

Watts, R., \& Zimmerman, J. (1986). Positive accounting theory. Edgewood Cliff, NJ.

Appendix

SPSS Output

Model Summary

\begin{tabular}{llllll}
\hline & & Adjusted & \multicolumn{2}{c}{ R Std. Error of the } \\
Model & R & R Square & Square & Estimate & Durbin-Watson \\
\hline 1 & $.380^{\mathrm{a}}$ & .144 & .134 & .339122737 & 1.758 \\
\hline
\end{tabular}

a. Predictors: (Constant), luas

b. Dependent Variable: T0 
Scatterplot

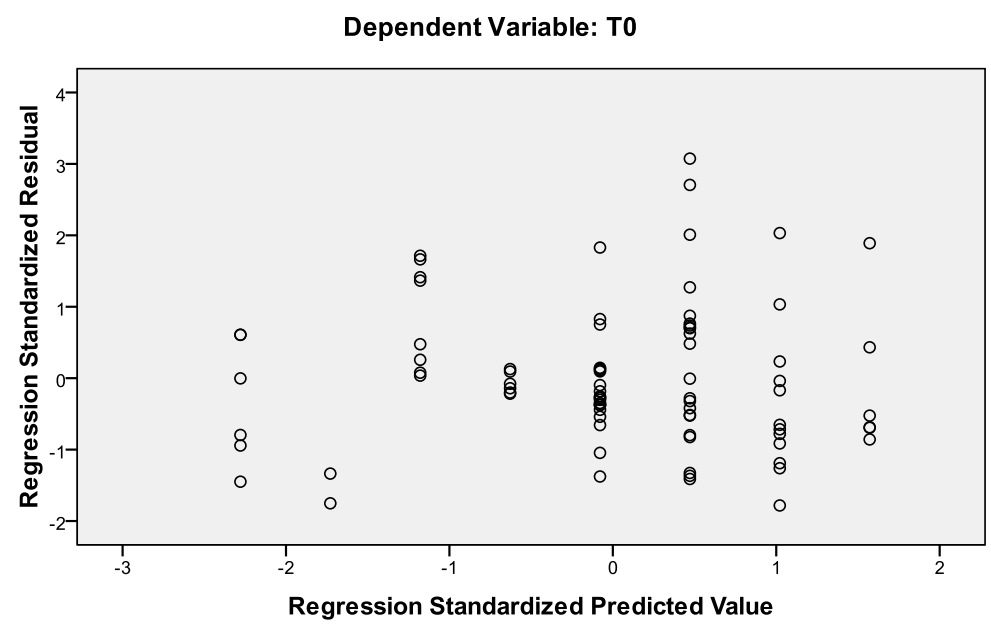

Correlations

luas Unstandardized Residual

\begin{tabular}{|c|c|c|c|c|}
\hline \multirow[t]{6}{*}{ Spearman's rho } & \multirow[t]{3}{*}{ luas } & \multicolumn{2}{|c|}{ Correlation Coefficient 1.000} & -.096 \\
\hline & & Sig. (2-tailed) & . & .384 \\
\hline & & $\mathrm{N}$ & 85 & 84 \\
\hline & \multirow[t]{3}{*}{ Unstandardized Residual } & Correlation Coeffic & -.096 & 1.000 \\
\hline & & Sig. (2-tailed) & .384 & . \\
\hline & & $\mathrm{N}$ & 84 & 84 \\
\hline
\end{tabular}

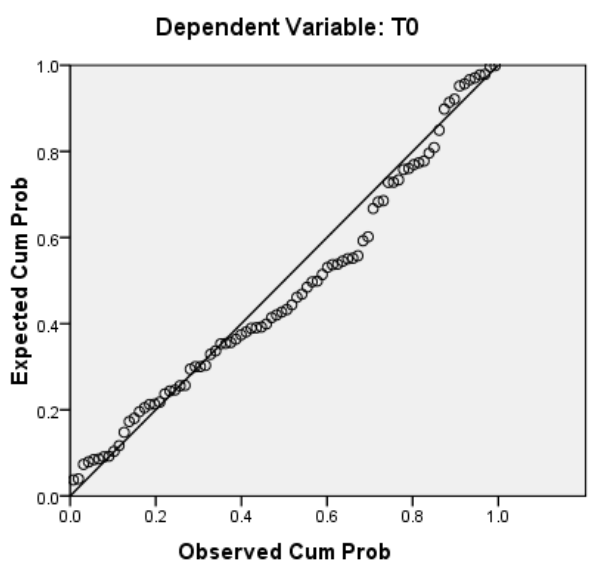


One-Sample Kolmogorov-Smirnov Test

\begin{tabular}{lll}
\hline & & $\begin{array}{l}\text { Unstandardized } \\
\text { Residual }\end{array}$ \\
\hline $\mathrm{N}$ & Mean & 84 \\
Normal Parameters & a,b & .0000000 \\
& Std. Deviation & .33707364 \\
Most Extreme Differences & Absolute & .121 \\
& Positive & .121 \\
& Negative & -.049 \\
Kolmogorov-Smirnov Z & & 1.106 \\
Asymp. Sig. (2-tailed) & & .173 \\
\hline a. Test distribution is Normal. & \\
b. Calculated from data. &
\end{tabular}

sampel DQO = 1

Model Summary $^{\text {b }}$

\begin{tabular}{llllll}
\hline & & Adjusted & \multicolumn{2}{c}{ RStd. Error of the } \\
Model & $\mathrm{R}$ & R Square & Square & Estimate & Durbin-Watson \\
\hline 1 & $.396^{\mathrm{a}}$ & .157 & .141 & .364377503 & 1.756 \\
\hline
\end{tabular}

a. Predictors: (Constant), luas

b. Dependent Variable: T0

sampel $D Q 0=0$

Model Summary ${ }^{b}$

\begin{tabular}{llllll}
\hline & & Adjusted & \multicolumn{2}{c}{ RStd. Error of the } \\
Model & $\mathrm{R}$ & R Square & Square & Estimate & Durbin-Watson \\
\hline 1 & $.384^{\mathrm{a}}$ & .148 & .116 & .296960832 & 1.495 \\
\hline
\end{tabular}

a. Predictors: (Constant), luas

b. Dependent Variable: T0

\section{Sampel $C G=1$}

Model Summary ${ }^{\mathrm{b}}$

\begin{tabular}{llllll}
\hline & & & & \multicolumn{2}{l}{ Std. Error of the } \\
Model & $\mathrm{R}$ & R Square & Adjusted R Square & Estimate & Durbin-Watson \\
\hline 1 & $.127^{\mathrm{a}}$ & .016 & -.033 & .400668738 & 1.798 \\
\hline
\end{tabular}

a. Predictors: (Constant), luas

b. Dependent Variable: T0 


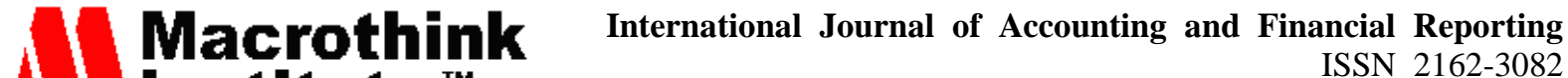 2018, Vol. 8, No. 1}

Sampel $C G=0$

Model Summary

\begin{tabular}{llllll}
\hline & & & Adjusted & \multicolumn{2}{c}{ RStd. Error of the } \\
Model & $\mathrm{R}$ & R Square & Square & Estimate & Durbin-Watson \\
\hline 1 & $.398^{\mathrm{a}}$ & .159 & .145 & .321471763 & 1.840 \\
\hline
\end{tabular}

a. Predictors: (Constant), luas

b. Dependent Variable: T0

Independent Samples Test

\begin{tabular}{|c|c|c|c|c|c|c|c|c|c|c|}
\hline & & \multicolumn{2}{|c|}{$\begin{array}{l}\text { Levene's Test } \\
\text { for Equality of } \\
\text { Variances }\end{array}$} & \multicolumn{7}{|c|}{ t-test for Equality of Means } \\
\hline & & & & & & & & & \multicolumn{2}{|c|}{$\begin{array}{c}95 \% \text { Confidence } \\
\text { Interval of the } \\
\text { Difference }\end{array}$} \\
\hline & & $\mathrm{F}$ & Sig. & $\mathrm{t}$ & $(2-1$ & $\begin{array}{l}\text { Sig. } \\
\text { 2-tailed) }\end{array}$ & $\begin{array}{c}\text { Mean } \\
\text { Difference }\end{array}$ & $\begin{array}{l}\text { Std. Error } \\
\text { Difference }\end{array}$ & Lower & Upper \\
\hline \multirow[t]{4}{*}{ luas } & $\begin{array}{l}\text { Equal variances } \\
\text { assumed }\end{array}$ & 5.756 & .019 & 4.496 & 83 & .000 & .09087 & .02021 & .05067 & .13107 \\
\hline & $\begin{array}{l}\text { Equal variances } \\
\text { not assumed }\end{array}$ & & & \multicolumn{2}{|c|}{5.81665 .642} & .000 & .09087 & .01562 & .05967 & .12207 \\
\hline & \multicolumn{7}{|c|}{ Group Statistics } & & & \\
\hline & $\mathrm{CG}$ & $\mathrm{N}$ & Mean & Std. & Deviation & Std. E & Error Mean & & & \\
\hline \multirow[t]{2}{*}{ luas } & 1 & 22 & .825 & & .05059 & & .01079 & & & \\
\hline & 0 & 63 & .734 & & .08972 & & .01130 & & & \\
\hline
\end{tabular}

\section{Copyright Disclaimer}

Copyright for this article is retained by the author(s), with first publication rights granted to the journal.

This is an open-access article distributed under the terms and conditions of the Creative Commons Attribution license (http://creativecommons.org/licenses/by/4.0/) 